\title{
THE COMPASSIONATE WAY Towards Trans and Non-Binary Inclusive Narratives in Museums
}

\section{ABSTRACT}

Often associated with compassion and mercy, Avalokiteshvara Guanyin is a figure that can possess masculine and feminine attributes, as well as exist in a space both between and beyond genders. The successful dissemination of the bodhisattva among communities has always involved metamorphoses and the being can also provide a new, and yet also very ancient, perspective on transgender and non-binary narratives in a museum context. There is a special opportunity for collections to adopt inclusive practice and use this figure as a way to connect with transgender and non-binary people

\section{ABSTRAKTI}

Avalokiteshvara Guanyin, joka yhdistetään usein myötätuntoon ja armollisuuteen, voi ilmentyä niin maskuliinisena kuin feminiinisenäkin hahmona ja ottaa paikkansa niin sukupuolten välissä kuin niiden tuolla puolenkin. Tämän muuntautumiskykyisen valaistuneen olennon tuleminen osaksi eri yhteisöjä voi tarjota museoille uuden, mutta samalla myös muinaisen näkökulman trans- ja muunsukupuolisiin narratiivihin. Näin se tarjoaa kokoelmille erityisen mahdollisuuden mukaan ottaviin käytäntöihin ja tavan luoda yhteyden trans- ja muunsukupuolisiin henkilöihin.
As I gazed up at the serene face, with heavily lidded eyes, without even looking at the label I knew who I was in the presence of. Wearing a five-pointed crown, delicately patterned robes, and holding up their right hand with incredibly well-detailed fingertips in a noble gesture, I could see the fifteenth century sculpture retained just enough flecks of bronze gilding to suggest how glorious it may once have been as a sacred object of reverence in a Buddhist temple in the Wutai Mountains of Shanxi in China. [Fig. 1.]

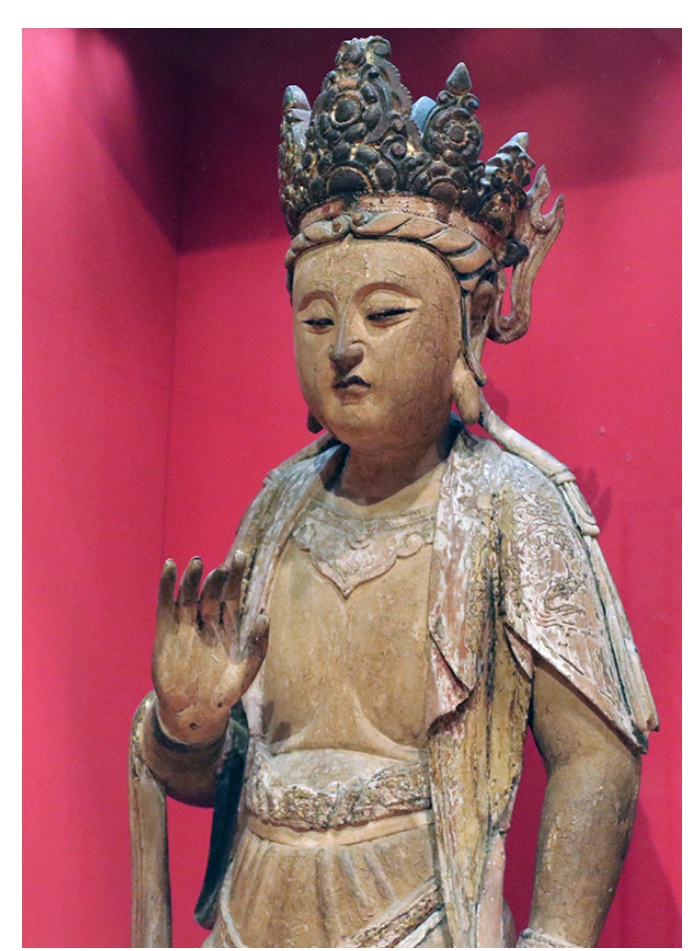

Fig 1. Avalokiteshvara Guanyin (15th century China) at Amgueddfa Genedlaethol Caerdydd National Museum Cardiff. Photo: Dan Vo. 
Standing in a sumptuously red-painted gallery in Amgueddfa Genedlaethol Caerdydd National Museum Cardiff, the figure of Avalokiteshvara Guanyin, the Buddhist bodhisattva associated with mercy and compassion, has been an unexpected connection in my ongoing work in developing LGBTQ+ tours in Cardiff, with the Victoria and Albert Museum in London, and the Fitzwilliam Museum in Cambridge. It was unexpected, because despite being very familiar with the icon throughout much of my childhood, there were aspects of the story which were not known to me until more recently. Growing up I was aware of the deity as a favourite of the hundreds of thousands of grateful refugee Vietnamese 'boat people' who had traversed watery horizons in search of a new home. Called Quan Am in Vietnamese, it was believed the being provided devotees safe passage from the perils of the sea, and the icon was often seen in local temples and domestic altars.

It wasn't until 2016 in the booklet Out In Oxford, which presented a trail of LGBTQ+ treasures across the University of Oxford's collections, that the potential for Avalokiteshvara Guanyin to provide a new, and yet also very ancient, perspective on transgender and non-binary narratives in a museum context was revealed to me. G R Mills described the seated figure of the bodhisattva in the Ashmolean Museum as an icon that was in a "transitional phase in the transformation of the male form of the bodhisattva Avalokiteshvara into the Chinese female deity Guanyin" (Ashmolean Museum. https://www.glam.ox.ac.uk/out-in-oxfordashmolean-museum). This referred to the centuries-long trek that the figure took, initially from the first century in India as Avalokiteshvara, crossing the Himalayas and arriving in China by the third century (Bailey 2009). During their journey the deity became "increasingly androgynous, incorporating both male and female characteristics". By the twelfth century in China the icon was almost entirely represented as the familiarly white robed Guanyin, the "one who hears the cries of the world" (Ashmolean Museum. https:// www.glam.ox.ac.uk/out-in-oxford-ashmolean-museum). As the figure moved further east into Korea, Japan and Vietnam, it also metamorphosed in ways that allowed the icon to fit within the needs of the receiving people: the successful dissemination of the bodhisattva into new communities required localisation and multiple transformations. The deity evolved into whatever form devotees needed most, and in museums today depictions might be called Avalokiteshvara or Guanyin, but may also be given the composite name Avalokiteshvara Guanyin.

In various places the gender fluidity was interpreted in different ways. For example, in the Vietnamese musical theatre Hat Cheo tradition, a morality tale dating from around the tenth century explains how an individual who bore much suffering throughout their life with boundless compassion became Quan Am Thi Kinh, the embodiment of Avalokiteshvara (Pham 2014). The play begins with Thi Kinh as a terribly wronged wife, who wanted to escape into a life of prayer, but could not because at the time it was considered the sole province of men. Thi Kinh assumed a male identity and became a monk, yet later in the story they are falsely accused of fathering a child with a local young woman. Even though their innocence could be proven through a biological defense, Thi Kinh maintains their male identity and instead accepts responsibility (Dharma Talk: Liberating Our Hearts - Practicing with the Paramita of Inclusiveness. \#29 Summer 2001. https://www.mindfulnessbell.org/archive/2015/12/dharma-talkliberating-our-hearts-practicing-with-the-paramita-of-inclusiveness-2). With this old folktale of Thi Kinh, we have an ancient tale which seems to deftly distinguish between gender roles and biological sex, while having a protagonist that challenges gender norms. Given the era in which the tale became popular, it is tantalising to consider the implications for the ancient audience. [Fig. 2.]

It is perhaps easier to assess the impact of such a story on contemporary transgender and non-binary people. I try to be careful when using pronouns 
to describe Guanyin, and I know I am not the only one to agonise over what might otherwise seem like a casual use of 'he / him / his' or 'she / her / hers'. In the T.T. Tsui gallery at the V\&A, which exhibits Chinese objects from the museum's vast collection, there are quite a few representations of Avalokiteshvara Guanyin. In one particular cabinet, the label for a grand sculpture with faded paint, dated between the fourteenth and sixteenth, explains, "she stands upright on a lotus" (Guanyin. Victoria \& Albert collections. http://collections.vam.ac.uk/item/ O493331/guanyin-figure-of-guanyin-unknown/). In an adjacent cabinet, there is a magnificent seated figure which, like the aforementioned one in Cardiff, also hails from Shanxi Province in China. This one is older, though, dating to around the thirteenth century. The bodhisattva adopts a position of calm repose called "royal ease", with the right knee bent and the right arm resting on it. The accompanying label uses the pronoun "he", though the online description does also include a reference to finely carved "faintly feminine features" (Guanyin. Victoria \& Albert collections. http://collections.vam.ac.uk/item/O72412/guanyin-figure-of-guanyinunknown/). [Fig. 3.]

On LGBTQ+ tours when I take people to these two sacred figures, I ask visitors to look carefully at the faces, the poses, the gestures, the slightly varied forms of dress. I ask them, "what do you think is masculine or feminine? At what stage of transition or androgenisation do you feel the figure is at?" After a short pause for reflection I then add, "as you consider these visual references, also ask yourself if it at all matters? Perhaps we should instead ask how you feel in their presence." Indeed, gender is said by some to be unimportant in attaining enlightenment, and attempting to hold onto binary positions may be unhelpful on such a journey. For me it also recalls a distant childhood memory, from when I was too young to understand the nuances of adult discussion and I overheard family members appraising the feminine and masculine attributes of the wood carved bodhisattva that lived on our family altar, ultimately with no resolution or judgement made. I believe this links with what author AKE at the Ashmolean Museum said on the matter, "in Mahayana Buddhism, physicality of gender is considered a delusion of the unenlightened". Indeed, a person of any gender may achieve enlightenment (Chennery 2015). When examining images of Avalokiteshvara Guanyin it may be therefore a folly to weigh up its maleness or femaleness, instead it may be more useful to consider the figure's "transcendence beyond gender" (Ashmolean Museum. https://www.glam.ox.ac.uk/out-in-oxford-ashmolean-museum).
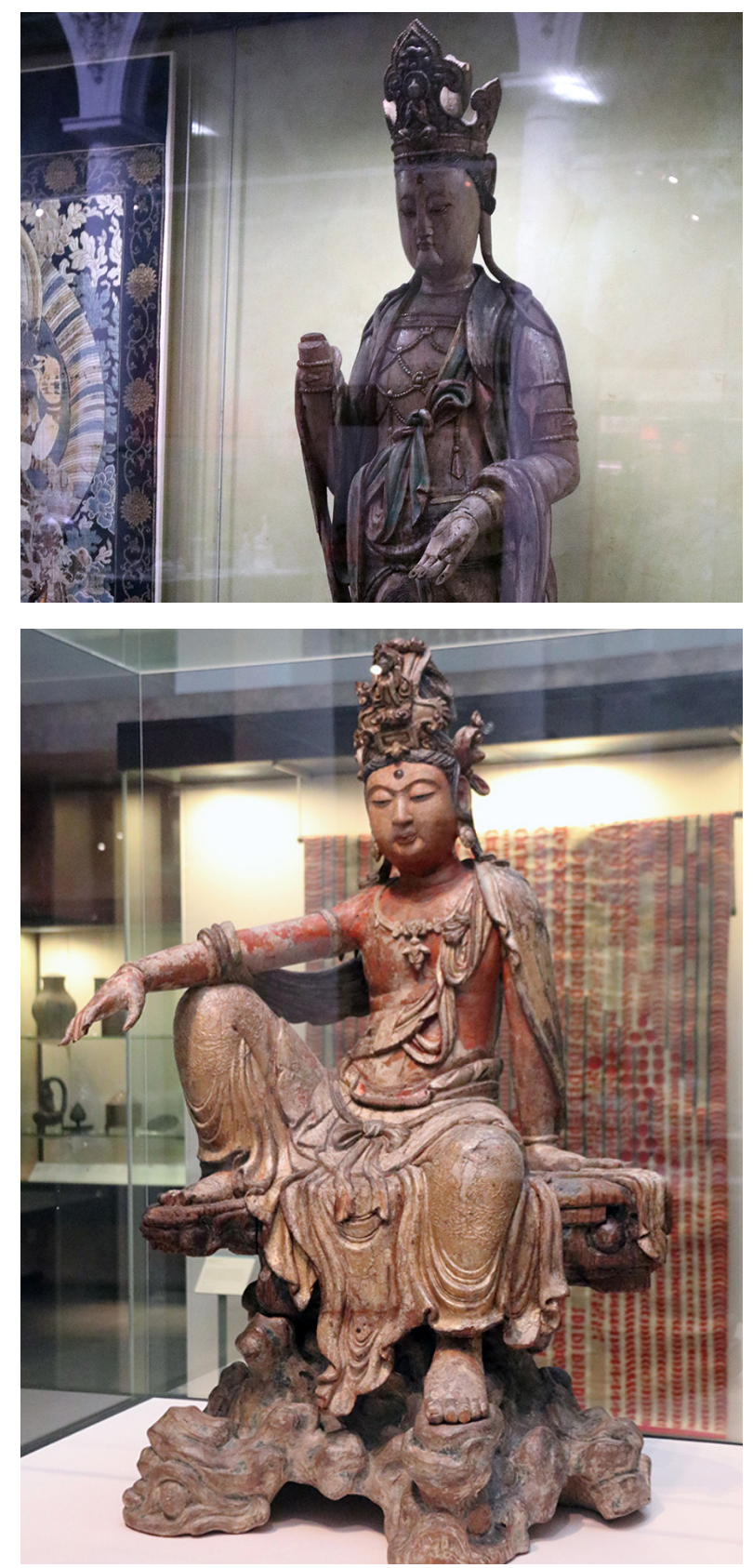

Fig 2. Female Guanyin (around 14-15th century China) at V\&A. Fig 3. Male Guanyin (13th century China) at V\&A. Photos: Dan Vo. 
It is Avalokiteshvara Guanyin's unsettled gender fluidity that has led to an increased interest in the icon's role among transgender and nonbinary communities. As a figure that can possess masculine and feminine attributes, as well as exist in a space both between and beyond genders, there is a logic to the association between Avalokiteshvara Guanyin and those who have a gender identity that is not that the sex assigned to them at birth, as well as those who identify as genderqueer, non-binary, agender, or somewhere along or even outside of the gender spectrum (Human Rights Campaign: Understanding the Transgender Community. https:// www.hrc.org/resources/understanding-the-transgender-community). Professor of Gender and Women's Studies at Western Michigan University, Cathryn Bailey, in her weighty treatise Embracing the Icon: The Feminist Potential of the Trans Bodhisattva, described Avalokiteshvara Guanyin's shifting gender and the way in which the figure "slips past male / female binary" as something that "startles, intrigues, and comforts, depending on one's circumstances" (Bailey 2009). In a museum context this icon of compassion also provides an opportunity for engagement with the diverse transgender and non-binary communities. [Fig. 4.]

For Laura Bauld, Project Curator at the Burrell Collection, the exploration of the transgender and non-binary narrative of the deity has allowed "inclusion through integration" (Bauld 2018). Prioritising the telling of the often hidden or underappreciated LGBTQ+ history of museum objects, through an ongoing collaborative partnership with Glasgow's LGBT Health and Wellbeing's T-Time group, trans and non-binary individuals have helped guide the museum's interpretation and reinforced the notion of Avalokiteshvara Guanyin, through their eyes, as a "transgender icon" (Bauld 2018). There is meaningful power behind Bauld's method of including often marginalised voices and raising them up to a level equal to that of the museum curator. Bailey put it succinctly, by saying, "part of what it means for a people to construct an identity is to construct a history, some sort of

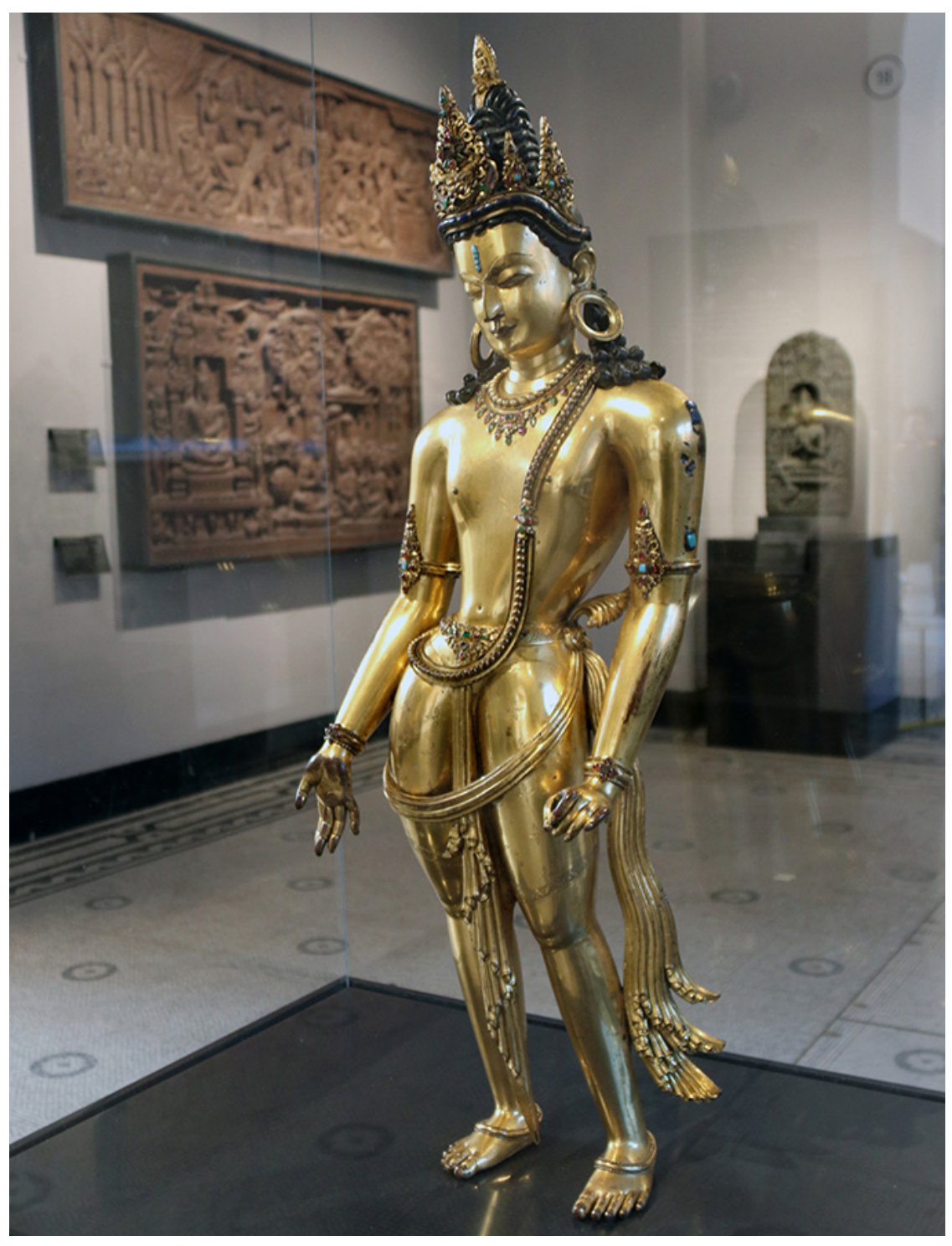

SQS

$1-2 / 2020$

98

Queer Mirror

Discussions

Fig 4. Avalokiteshvara (14th century Nepal) at V\&A. Photo: Dan Vo. 
cultural memory, the inclusion of a figure like (Avalokiteshvara Guanyin) as trans icon is especially important" (Bauld 2018).

It is clear that transgender and non-binary people are included in some of the most vulnerable and at risk minority groups. In this context, it might be said that museum activities that support and engage with transgender and non-binary communities have real urgency. Museums have a responsibility in shaping community and culture, and challenging intolerance and prejudice (Museums Association: Museum Manifesto for Tolerance and Inclusion. https://www.museumsassociation.org/ download?id=1214164).

Recently, my work with the volunteer team of guides who lead the LGBTQ+ Tour at the V\&A has led to an adoption of a values-led approach to training and recruitment, as well as the reinforcement of our affirmative practices to be more inclusive. We make it clear we proudly support transgender and non-binary people. At the start of each meeting we acknowledge that we have marginalised voices missing from the table, and commit ourselves to making it possible for them to join. This may include people of colour, those from working class backgrounds, disabled people, as well as people from a diversity of religious and cultural beliefs. While we do have transgender and non-binary colleagues, we would always encourage more to join. [Fig. 5.]

Having a more diverse team means the objects that we interpret and present will be more varied, and we would therefore better represent our audience. It is a sensible approach in our goal to show the existence of LGBTQ+ people throughout time, place and culture. Furthermore, as museum workers, in taking this stance, it is not just a fulfilment of our public duty to uphold the tenets of the Equality Act 2010, which provides a range of legal protections to transgender people in the $\mathrm{UK}$, but also a true act of human compassion. Much of my own values-led work has stemmed from a long standing relationship with LGBT+ History Month. Initiated

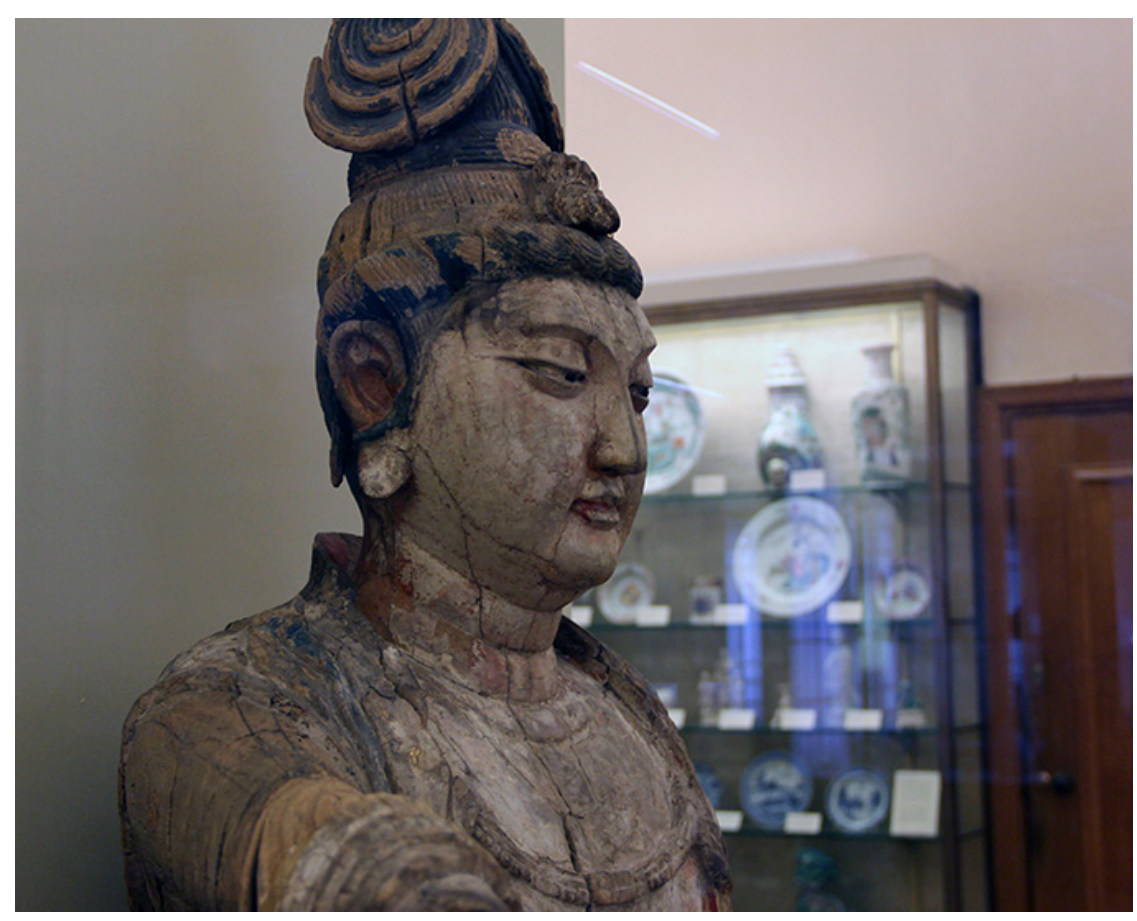

SQS

$1-2 / 2020$

99

Queer Mirror

Discussions

Fig 5. Guanyin (14th century China) at Fitzwilliam Museum. Photo: Dan Vo.

in the UK in 2015 by Sue Sanders and Paul Patrick, each year museums around the country mark February with relevant LGBTQ+ themed public programming (Barr 2019). Since 2015 I have been involved initially as a volunteer, then also as a lecturer, and more recently as a patron. In a museum context I develop LGBTQ+ tours and programming: Amgueddfa Genedlaethol Caerdydd National Museum Cardiff, Gunnersbury Park Museum, National Gallery, Imperial War Museum, Queer Britain, Tate Britain, University of Cambridge Museums, and others. It is at the heart of my work as the project leader for the UK Queer Heritage and Collections Network founded by English Heritage, Historic England, Historic Royal Palaces, the National Trust and the Research Centre for Museums and Galleries at the University of Leicester. [Fig. 6.] 


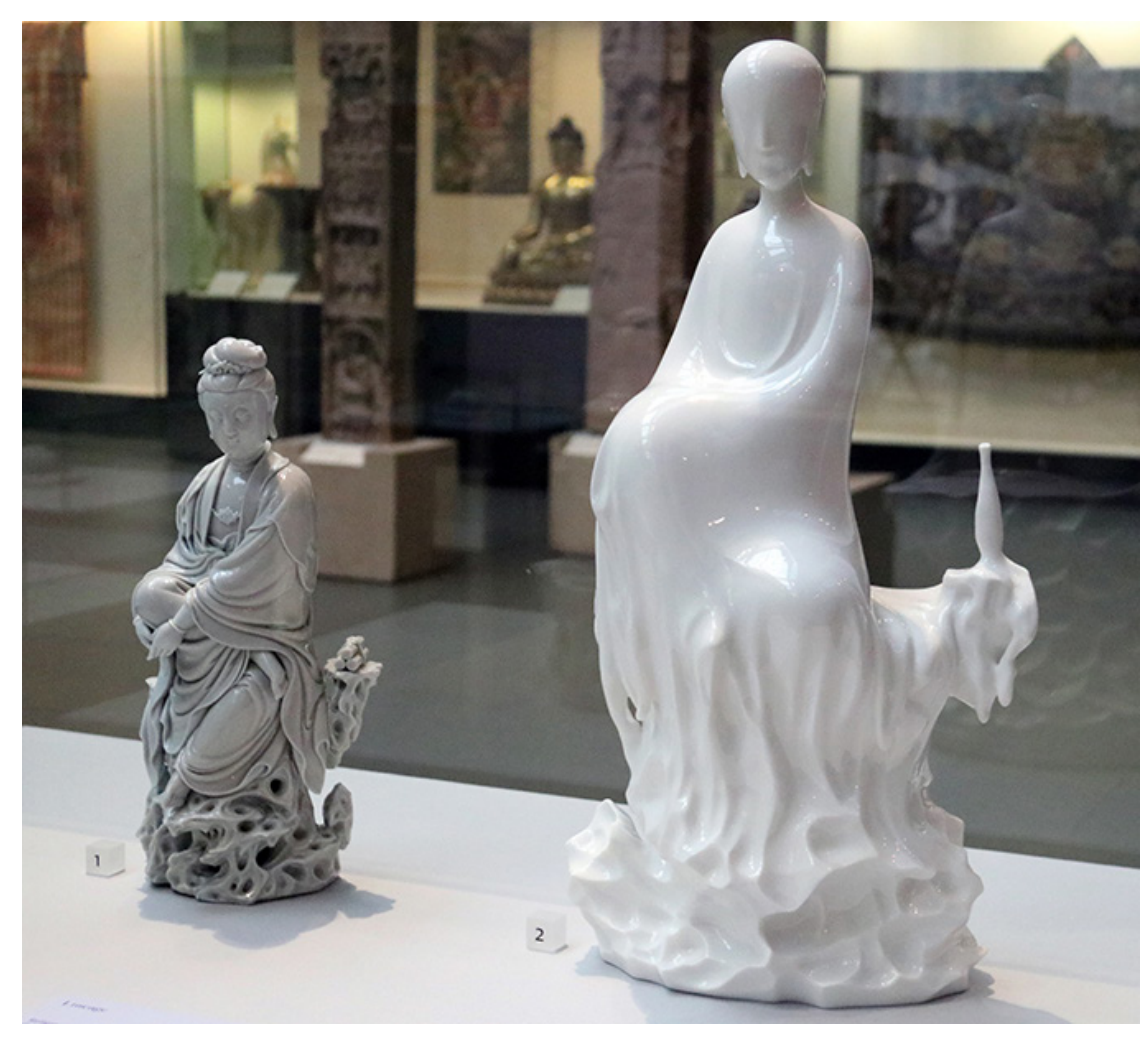

Fig 6. Guanyin (17th century China) beside Meeting by Su Xianzhong (2018) at V\&A. Photo: Dan Vo

In 2020 for International Transgender Day of Visibility on March 31 Amgueddfa Genedlaethol Caerdydd National Museum Cardiff posted a video with an image of the Avalokiteshvara Guanyin from the collection with the statement, "Avalokiteshvara Guanyin helps explain the diverse understanding of gender and sexuality many ancient communities had" (Amgueddfa Genedlaethol Caerdydd National Museum Cardiff. 2020. “Today is Trans Visibility Day”. Twitter, March 31, 2020. https://twitter. com/Museum_Cardiff/status/1244995159709843457?s=20). Indeed, for transgender activist Pauline Park, Avalokiteshvara Guanyin is part of a long roll call of Asian mythological and legendary narratives that involves the sexual transformation of individuals she calls "proto-transgenderal": those who may be considered transgender centuries before the term was used (Park 2011). It can be suggested such narratives were suppressed, obscured or obliterated following the period of colonial contact and still even potentially difficult in a supposedly post-colonial world. Yet, the act of decolonisation in a museum context is now a possibility, and the understanding and sharing of stories of difference and diversity, alongside stories of unity and inclusion is essential. For our transgender and non-binary visitors coming to see Avolokiteshvara Guanyin, as Park so eloquently puts it, "it is fitting that mercy should be the province of transgendered people, because of the power of the tranformation teaches compassion to the transformed" (Park 2013).

\section{References}

Amgueddfa Genedlaethol Caerdydd National Museum Cardiff. 2020. "Today is Trans Visibility Day". Twitter, March 31, 2020. https:/twitter.com/ Museum_Cardiff/status/1244995159709843457?s=20

Ashmolean Museum. https://www.glam.ox.ac.uk/out-in-oxford-ashmoleanmuseum

Bailey, Cathryn. 2009. Embracing the Icon: The Feminist Potential of the Trans Bodhisattva, Kuan Yin. Hypatia, a special issue Transgender Studies and Feminism: Theory, Politics, and Gendered Realities, 24:3, 178-196. https://www.jstor.org/stable/20618170?seq=1

Barr, Sabrina. 2019. "LGBT History Month" Independent, February 7, 2019. https://www.independent.co.uk/life-style/lgbt-history-month-ukwhen-february-lesbian-gay-bisexual-transgender-queer-communitycelebration-a8755966.htm

Bauld, Laura. Email to author, 13 July, 2018.

Chennery, Carolynn. 2015. Destroying the Binary: Transgenderism in Buddhism. RELIG ST 4H03. https://dc.uwm.edu/cgi/viewcontent. cgi?article $=1045 \&$ context $=$ rsso 
Dharma Talk: Liberating Our Hearts - Practicing with the Paramita of Inclusiveness. \#29 Summer 2001. https://www.mindfulnessbell.org/ archive/2015/12/dharma-talk-liberating-our-hearts-practicing-with-theparamita-of-inclusiveness-2

Guanyin. Victoria \& Albert collections. http://collections.vam.ac.uk/item/ O493331/guanyin-figure-of-guanyin-unknown/

Guanyin. Victoria \& Albert collections. http://collections.vam.ac.uk/item/ O72412/guanyin-figure-of-guanyin-unknown/

Human Rights Campaign: Understanding the Transgender Community. https:// www.hrc.org/resources/understanding-the-transgender-community

Museums Association: Museum Manifesto for Tolerance and Inclusion. https:// www.museumsassociation.org/download?id=1214164

Park, Pauline. 2011. Proto-transgenderal Homoerotic Traditions in Asia and the Pacific. Pacific School of Religion. https://paulinepark.com/prototransgenderal-homoerotic-traditions-in-asia-the-pacific/

Park, Pauline. 2013. Transgender Identities and Spiritual Traditions in Asia and the Pacific: Lessons for LGBT/Queer APIs. Pacific School of Religion. https:// paulinepark.com/transgender-identities-spiritual-traditions-in-asia-thepacific-lessons-for-lgbtqueer-apis-pacific-school-of-religion-4-2-13/

Pham, PQ. 2014. The Tale of Lady Thi Kinh - Programme. Indiana: Indiana University Jacobs School of Music. 